\title{
Efektifitas Media Dadu Putar Untuk Kesiapan Membaca Anak Usia Dini
}

\author{
Rita Kurnia \\ Universitas Riau \\ Email : rita.kurnia@,1ecturer.unri.ac.id
}

DOI: $10.31849 /$ paud-lectura.v\%vi\%i.4644

Received 29 Juli 2020, Accepted 10 Agustus 2020, Published 1 Oktober 2020

\begin{abstract}
Abstrak
Penelitian ini bertujuan untuk kesiapan membaca anak dengan menggunakan media dadu putar. Penelitian ini menggunakan metode eksperimen dengan desain one group pre - test post - test design. Sampel yang digunakan adalah 15 orang anak usia dini. Teknik pengumpulan data adalah pedoman observasi. Teknik analisis data menggunakan uji $t$ - test dengan menggunakan program SPSS 16. Berdasarkan analisis data sebelum diberikan perlakuan lima indikator pada kategori belum berkembang (BB), mulai berkembang (MB), untuk mengetahui lebih dalam tentang kesiapan membaca dan upaya efektif untuk meningkatkan perkembangan sesuai harapan (BSH) dan berkembangan sangat baik (BSB). Hasil penelitian mengungkapkan terdapat pengaruh media dadu terhadap kesiapan membaca anak usia 3-4 tahun di Pekanbaru Riau Indonesia yang signifikan yaitu sebesar 50,87\%.
\end{abstract}

Kata kunci: Anak Usia Dini, Kesiapan Membaca, Media Dadu Putar

\author{
The Effectiveness of the Play Dice Media for Readiness of Early Childhood Reading \\ Rita Kurnia \\ Universitas Riau \\ Email : rita.kurnia@lecturer.unri.ac.id
}

\begin{abstract}
This study aims to read children's readiness by using dice media. The study used an experimental method with one group pre-test post-test design. The sample used was 15 early childhood. Data collection technique is observation. Data analysis technique used t-test using SPSS 16. Based on data analysis before being given treatment of five indicators in the undeveloped (BB) category, began to develop (MB), to find out more about reading readiness and effective efforts to improve development according expectation (BSH) and very well developed (BSB), there is a significant influence of dice media on readiness of children aged 3-4 years in Pekanbaru Riau Indonesia, which is equal to $50.87 \%$.
\end{abstract}


Keywords: Early Childhood, Reading Readiness, Play Dice Media

\section{PENDAHULUAN}

Anak usia dini diharapkan dapat melengkapi dirinya dengan berbagai kemampuan yang dibutuhkan untuk belajar lebih lanjut di sekolah dasar seperti kemampuan membaca permulaan, kestabilan emosi, kemampuan sosial, atau motivasi. Hasil penelitian menunjukkan bahwa orang tua memainkan peran penting dalam mempersiapkan anak-anak mereka ke sekolah dasar, (King \& With, 2002). Teori pembangunan menekankan pembelajaran membaca juga melibatkan peran konteks dan faktor psikologis lingkungan, (Ryoo et al., 2015). Hasil penelitian menunjukkan bahwa anakanak di taman kanak-kanak negeri lebih lancar membaca daripada anak-anak di taman kanak-kanak swasta, bahwa perolehan keterampilan berbahasa sebenarnya tergantung pada paparan dan pengalaman belajar pengajaran bahasa yang diterima oleh anak, (Kurnia, 2012). Menurut (Pallant, 2013) anak-anak yang mengalami program keterampilan pra baca yang baik pada tingkat prasekolah lebih siap menggunakan keterampilanketerampilan tersebut dalam tugas membaca di tingkat awal sekolah dasar.

Hasil penelitian menunjukkan bahwa melalui media kartu huruf bergambar dapat ditingkatkan kesiapan belajar secara signifikan, bila permainan dapat dilakukan dengan baik, media pembelajaran dalam upaya peningkatan kesiapan membaca anak, khususnya anak usia 3-4 tahun, (Novianti, 2015). Hasil tes kesiapan membaca dilakukan untuk menolong anak usia dini yang kurang mampu. Orang tua memerlukan informasi dari taman kanak-kanak untuk memungkinkan mereka bekerja sama dengan sekolah dasar di kelas satu untuk memperbaiki kemampuan kesiapan anak usia dini mencapai tahap yang memuaskan. Penelitian-penelitian juga menunjukkan bahwa orang tua memainkan peran yang penting dalam menyiapkan anak-anak mereka ke sekolah dasar, (Roring, 2013)

Tahap kesiapan membaca adalah berbeda-beda menurut pengalaman sewaktu di taman kanak-kanak, lokasi TK, jenis TK, dan status ekonomi orang tua, (Majzub \& Kurnia, 2010). Dari pihak pemerintahan untuk menampung masalah ini mungkin dapat diringankan jika orang tua juga memainkan peran aktif dalam menyiapkan anak-anak mereka membaca lebih awal. Orang tua mampu meningkatkan kesiapan anakanak mereka membaca permulaan jika mereka mempunyai pengetahuan, kemampuan, dan dukungan yang diperlukan untuk menjalankan gaya keorangtuaan yang positif dan melakukan aktifitas-aktifitas yang dapat merangsang perkembangan anak-anak mereka dari awal lagi, (Wahyuni \& Reswita, 2018). Anak usia dini yang mempunyai tahap kesiapan membaca yang tinggi akan melangkah ke sekolah dasar di kelas satu dengan mudah dan 
mampu menyesuaikan diri dan menerima pembelajaran formal yang berlaku di sekolah untuk tahun-tahun berikutnya.

Keberhasilan kesiapan membaca pada anak usia dini perlunya instrumen yang tepat mengikuti perkembangan bahasa khususnya banyaknya kosakata anak, oleh karena itu ketersediaan media pembelajaran yang dimiliki sekolah relatif terbatas seperti jenis media, jumlah media, dan kualitas media sehingga kelancaran pelaksanaan pembelajaran kurang efektif, (Kurnia, 2014). Menurut Horocks dan Schoonover dalam (Majzub \& Kurnia, 2010) mengatakan bahwa kesiapan membaca individu melibatkan dirinya dan pengalaman belajar di sekolah dan faktor dari kesiapan membaca yaitu kesiapan fisik, kesiapan psikologis, kesiapan pendidikan dan kesiapan IQ. Keempat faktor ini saling mendukung satu dengan yang lainnya, (Fahim \& Mustafa, 2001).

Hal ini sesuai pendapat Tsu (Ahmad Susanto, 2011) yang lebih menekankan kesiapan membaca pada keadaan motovasi diri dan perilaku yang menunjukkan adanya kesiapan mental, kemauan belajar terhadap lingkungan secara umum dan khususnya teks bacaan atau gambar, seperti: 1) Rasa ingin tahu tentang benda-benda di dalam lingkungan, manusia, proses, dan sebagainya; 2) mampu untuk menerjemahkan atau membaca gambar dengan mengidentifikasi dan menggambarnya; 3) menyeluruh dalam pembelajaran;

4) kemampuan berkomunikasi dengan bahasa percakapan khususnya dalam kalimat; 5) kemampuan untuk membedakan dan persamaan serta perbedaan dalam suara secara cukup baik; 6) adanya kengingan untuk belajar membaca; 7) memiliki kemampuan emosional yang cukup untuk dapat konsentrasi dan terusmenerus dalam suatu tugas; 8) memilliki percaya diri dan stabilitas emosi.

Menurut (Chairilsyah \& Kurnia, 2018) mengatakan bahwa media (alat) dalam pengajaran melalui simulasi dari inti pengajaran yang disampaikan baik secara deskriptif maupun demonstrasi yang tentunya ini menandakan pada fungsinya sebagai penyampaian pesan, serta dalam konteks media pembelajaran bagi anak usia dini, media merupakan segala alat fisik yang dapat menyajikan pesan serta merangsang anak didik untuk belajar. Media dadu putar adalah sama dengan media visual, media yang menyampaikan pesan melalui penglihatan pemirsa atau media yang hanya dapat dilihat (Kurnia \& Solfiah, 2018). Prinsip pengembangan media dadu putar yang perlu diperhatikan pendidik PAUD diantaranya: (1) Akomodatif pada kebutuhan dan tahapan perkembangan anak. (2) Menarik dan menyenangkan. (3) Memanfaatkan pontensi dan sumber daya yang ada dilingkungan sekitar, termasuk bahan bekas layak pakai.

Kesiapan membaca awal pada anak seperti yang telah dijelaskan sebelumnya, untuk meningkatkan kesiapan membaca awal pada anak 
dapat menggunakan media dadu putar mengenal bermacam huruf, mengenal warna, bentuk geometri, dan anak dapat mengenal binatang dan tumbuhan disetiap tema pembelajaran.

\section{METODE PENELITIAN}

Penelitian ini dilakukan di Taman Kanak-Kanak Tunas Cahaya Kurnia, di Pekanbaru Riau. Populasi penelitian ini adalah anak usia 3-4 tahun di kelompok bermain (KB) dan sampel penelitian adalah sebanyak 15 orang anak, yakni 8 orang laki-laki dan 7 orang perempuan.

\begin{tabular}{|c|c|c|c|c|c|}
\hline $\begin{array}{l}\text { PeNelitian ini adalah penelitian } \\
\text { eksperimen, menggunakan The Pre }\end{array}$ & Indikator & $\begin{array}{l}\text { Skor } \\
\text { Faktual }\end{array}$ & $\begin{array}{l}\text { Skor } \\
\text { Ideal }\end{array}$ & $\%$ & Kriteria \\
\hline $\begin{array}{l}\text { Test-Post Test Design. Teknik } \\
\text { pengumpulan data, Pre Test sebelum }\end{array}$ & $\begin{array}{l}\text { Menunjukkan } \\
\text { Keinginan } \\
\text { Memegang buku }\end{array}$ & 25 & 60 & 42 & MB \\
\hline média dadu putar sebagai media & $\begin{array}{l}\text { Minta dibacakan } \\
\text { buku }\end{array}$ & 29 & 60 & 48 & MB \\
\hline $\begin{array}{l}\text { pembaca permulaan anak usia } \\
\text { kesiapan membal dilakukan }\end{array}$ & $\begin{array}{l}\text { Membaca dari kartu } \\
\text { huruf atau gambar }\end{array}$ & 27 & 60 & 45 & MB \\
\hline $\begin{array}{l}\text { pengukuran awal (Pretest). Pretest } \\
\text { dimaksudkan cuntuk mengetahui }\end{array}$ & $\begin{array}{l}\text { Menyebutkan nama } \\
\text { benda dan fungsinya } \\
\text { berdasarkan gambar }\end{array}$ & 20 & 60 & 33 & MB \\
\hline $\begin{array}{l}\text { kesiapan membaca permulaan pada } \\
\text { anak. Hasil pretest yang akan }\end{array}$ & $\begin{array}{l}\text { Menceritakan } \\
\text { gambar yang } \\
\text { dibuatnya sendiri }\end{array}$ & 28 & 60 & 47 & MB \\
\hline dibandingkan dengan hasil post test & Jumlah & 129 & 300 & 215 & \\
\hline setelah perlakuan diberikan. Pos Test, & Rata-rata & & & 43 & MB \\
\hline
\end{tabular}
dilakukan setelah eksperimen selesai dilaksanakan yang dimaksudkan untuk mengetahui eksperimen benar-benar ada pengaruh efektivitas media dadu putar untuk meningkatkan kesiapan membaca awal. Postest dilakukan pada kegiatan penutup pembelajaran anak pada hari eksperimen dilaksanakan.

\section{HASIL PENELITIAN DAN PEMBAHASAN}

\section{Gambaran Kesiapan Membaca Anak} Usia 3-4 Tahun Sebelum Perlakuan

Berdasarkan pretest yang dilakukan pada anak usia 3-4 tahun di TK Tunas Cahaya Kurnia Riau dengan cara observasi langsung, maka diperoleh gambaran kesiapan membaca permulaan pada anak.

Tabel 1. Kesiapan Membaca Anak Usia 3-4 Tahun Di TK Tunas Cahaya Kurnia Riau Sebelum Diberikan Kegiatan Media Dadu Putar 
diberi perlakuan yaitu $43 \%$ berada pada kriteria mulai berkembang (MB).

\section{Persentasi Pretest}

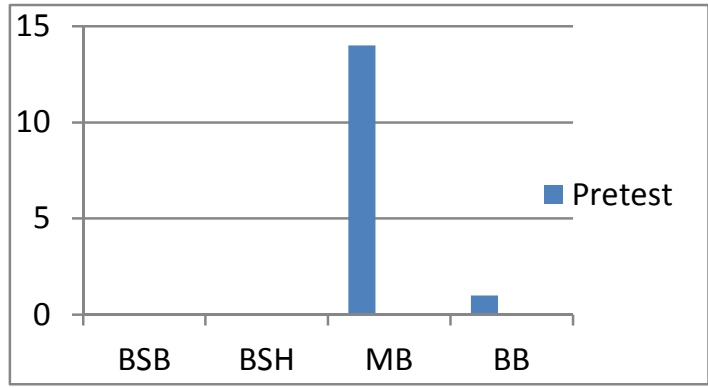

Gambar 1. Kesiapan Membaca Permulaan Sebelum Perlakuan

\section{Gambaran Kesiapan Membaca Anak Usia 3-4 Tahun Setelah Perlakuan}

Setelah perlakuan dengan menggunakan media dadu putar pada anak usia 3-4 tahun di TK Tunas Cahaya Kurnia Riau, diperoleh hasil kesiapan membaca anak usia 3-4 tahun berdasarkan hasil postest.

Tabel 2. Kesiapan Membaca Anak Usia 3-4 Tahun Di TK Tunas Cahaya Kurnia Riau Setelah Diberikan Kegiatan Media Dadu Putar

\begin{tabular}{lccccc}
\hline No Indikator & $\begin{array}{c}\text { Skor } \\
\text { Faktual }\end{array}$ & $\begin{array}{c}\text { Skor } \\
\text { Ideal }\end{array}$ & $\%$ & Kriteria \\
\cline { 1 - 4 } 1 & $\begin{array}{l}\text { Menunjukkan } \\
\text { keinginan } \\
\text { memegang buku }\end{array}$ & 45 & 60 & 75 & BSH \\
\hline 2 & $\begin{array}{l}\text { Minta dibacaka } \\
\text { buku }\end{array}$ & 43 & 60 & 72 & BSH \\
\hline 3 & $\begin{array}{l}\text { Membaca dari kart } \\
\text { huruf atau gambar }\end{array}$ & 44 & 60 & 73 & BSH
\end{tabular}

\begin{tabular}{llllll}
\hline 4 & $\begin{array}{l}\text { Menyebutkan nam } \\
\text { benda } \\
\text { fungsinya } \\
\text { berdasarkan gamba }\end{array}$ & 40 & 60 & 67 & BSH \\
\hline 5 & $\begin{array}{l}\text { Menceritakan } \\
\text { gambar yan } \\
\text { dibuatnya sendiri }\end{array}$ & 46 & 60 & 76 & BSB \\
\hline Jumlah & 216 & 300 & 363 & \\
\hline Rata-rata & & & 72 & BSH \\
\hline
\end{tabular}

Hasilnya menunjukkan bahwa skor akhir tertinggi terdapat pada indikator lima (5) yaitu menceritakan gambar yang dibuatnya sendiri dengan skor 46 persentasi $76 \%$ berada pada kriteria berkembang sangat baik (BSB). Skor akhir terendah terdapat pada indikator empat (4) yaitu menyebutkan nama benda dan fungsinya berdasarkan gambar dengan skor 40 persentasi $67 \%$ berada pada kriteria berkembang sesuai harapan (BSH). Kesimpulannya, bahwa persentase pada indikator tersebut telah diberi perlakuan $72 \%$ berada pada kriteria berkembang sesuai harapan (BSH).

\section{Perbandingan Data Pretest dan Posstes}

Perbandingan kesiapan membaca anak usia 3-4 tahun sebelum diberikan perlakuan (pretest) dan setelah diberikan perlakuan (posttest) di TK Tunas Cahaya Kurnia Riau.

Tabel 3. Rekapitulas Kesiapan Membaca Permulaan Sebelum dan Sesudah Diberikan Kegiatan Media Dadu Putar Di di TK Tunas Cahaya Kurnia Riau

\begin{tabular}{llllllc}
\hline N & Kategori & \multicolumn{2}{c}{$\begin{array}{c}\text { Rentang } \\
\text { Skor }\end{array}$} & \multicolumn{2}{c}{ Sebelum } & \multicolumn{2}{c}{ Sesudah } \\
1. & & F & F & \% \\
\hline 1. & BSB & $76-100 \%$ & 0 & $0 \%$ & 4 & $26,66 \%$
\end{tabular}




\begin{tabular}{lllllll} 
2. & BSH & $56-75 \%$ & 0 & $0 \%$ & 11 & $\overline{73,33 \%}$ \\
3. & MB & $41-55 \%$ & 14 & $93,3 \% 0$ & $0 \%$ \\
4. & BB & $<40 \%$ & 1 & $6,66 \% 0$ & $0 \%$ \\
\hline
\end{tabular}

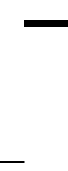

Tabel 4. Paired Samples Test

Paired Differences

$15 \%$ Confidence

Std. Std. Interval of the

'ig. (2-

$n \quad$ tion Mean Lower Jpper $t$ Df ed)

'air 1 vretest -

$\begin{array}{lllllllll}\text { posttest }, 80 & 2,178 & 562 & -7,006 & 4,594 & - & 14 & 0,315 & \end{array}$

Berdasarkan tabel empat (4) di atas, menunjukkan nilai uji statistik $t_{\text {hitung }}$ sebesar $=-10,315$ uji dua pihak berarti harga mutlak, sehingga nilai (-) tidak dipakai (Sugiyono, 2010) sehingga thitung 10,315 karna nilai (Sig. 2-tailed) $=$ $0,00<0,05$. Maka dapat peneliti simpulkan bahwa terdapat pengaruh media dadu putar yang sangat signifikan terhadap kesiapan membaca anak usia 3-4 tahun dalam pembelajaran.

Untuk mengetahui hipotesis diterima atau ditolak berdasarkan data SPSS ver. 16 dapat dilihat dari perbandingan hasil thitung dengan nilai $t_{\text {tabel }}$ yaitu hasil dari perhitungan uji $t$, terlihat bahwa hasil $t_{\text {hitung }}=10,315$ lebih besar dari pada $t_{\text {tabel }}=2,145$ dengan $\mathrm{df}$ yaitu:

$$
\text { Df } \quad \begin{aligned}
= & (\mathrm{n}-1) \\
& =15-1 \\
& =14
\end{aligned}
$$

Dengan $\mathrm{df}=14$, maka dapat dilihat harga $t_{\text {hitung }}=10,315$ lebih besar dari pada $t_{\text {tabel }}=2,145$. Dengan demikian Ho $=$ ditolak dan $\mathrm{Ha}=$ diterima. Berarti dalam penelitian ini terdapat pengaruh g. media dadu putar untuk meningkatkan takesiapan membaca anak usia 3-4 tahun Lea Devia Error Interval of the

$n$ tion Mean Lower Jpper $t$ If eddi TK Tunas Cahaya Kurnia Riau. 
Berdasarkan hasil hitung rumusan $\mathrm{N}$ - dapat disimpulkan bahwa pengaruh yang diberikan penggunaan media dadu putar untuk meningkatkan kesiapan membaca anak usia 3-4 tahun di TK Tunas Cahaya Kurnia Riau adalah sebesar 50,87\%. Pada kategori Gain ternormalisasi berada pada kategori sedang $30 \%<50,87<70 \%$.

Perkembangan bahasa pada anak usia dini, khususnya anak usia 3-4 tahun sangat penting diperhatikan melalui tindakan dan perlakuan pembelajaran tepat dan berkualitas terutama dalam membaca permulaan. Membaca merupakan sebuah aktivitas dari berbagai organ tubuh. Penelitian yang sama dilakukan Rohaty dan Rita Kurnia (2010), orang tua berpendidikan memiliki kemampuan untuk memberikan tunjuk ajar kepada anaknya bagaimana cara membaca. Orang tua yang miskin dapat didefinisikan sebagai orang tua yang memiliki pendidikan tingkat pendidikan rendah, (Wahyuni \& Reswita, 2017). Hasil penelitian juga menunjukkan bahwa anak usia dini telah mencapai prestasi yang tinggi dalam ujian kosa kata, diskriminasi auditori, diskriminasi visual, dan membaca mekanis.

Dari hasil penelitian yang dilakukan pada anak usia 3-4 tahun di TK Tunas Cahaya Kurnia Riau, dapat dilihat hasil pretest kesiapan membaca anak usia 3-4 tahun di TK Tunas Cahaya Kurnia Riau, diperoleh jumlah nilai 129 dengan rata-rata 43\%. Jika dilihat dari kriteria perorangan, tidak ada anak yang berada pada kriteria berkembang sangat baik (BSB) dan berkembang sesuai harapan (BSH) atau $0 \%$, yang berada pada kriteria mulai berkembang (MB) sebanyak 14 anak atau $93,3 \%$ dan terdapat anak yang berada pada kriteria belum berkembang (BB) sebanyak 1 anak atau 6,66\%. Hasil penelitian Rita Kurnia, Hukmi, dan Defni (2018) adapun kesiapan membaca anak kelas eksperimen setelah diberi perlakuan (treatmen) adalah 87,18. Artinya setelah diberi perlakuan, kelompok eksperimen memperoleh skor lebih tinggi dari pada kelompok kontrol. Hal ini juga memberi gambaran adanya peningkatan kesiapan membaca anak setelah diberlakukan media cerita bergambar cerita rakyat Melayu dengan tokoh utama Kancil.

Pada hasil Pretest skor tertinggi terdapat pada indikator dua "minta dibacakan buku" dengan jumlah skor 29. Indikator ini mendapatkan nilai tertinggi dikarenakan hampir semua anak minta untuk dibacakan buku, namun masih ada beberapa anak yang masih belum minta dibacakan buku. Kemudian skor terendah terdapat pada indikator empat "menyebutkan nama benda dan fungsinya berdasarkan gambar" dengan jumlah skor 20 . Indikator ini mendapatkan nilai terendah karena anak masih belum bisa menyebutkan nama benda dan fungsinya berdasarkan gambar tersebut. Ini sehubungan dengan penelitian (Solfiah et al., 2019), tingkat sosial ekonomi orang tua mempengaruhi kemampuan penguasaan kosakata murid taman kanak-kanak, maka bimbingan dan pengarahan dari seorang guru sangat diperlukan. 
Pada hasil posttest Skor akhir tertinggi terdapat pada indikator lima "menceritakan gambar yang dibuatnya sendiri" dengan jumlah skor 46. Indikator ini mendapatkan nilai tertinggi dikarenakan anak bisa menceritakan semua isi gambar yang dibuatnya sendiri. Kemudian skor terendah terdapat pada indikator empat "menyebutkan nama benda dan fungsinya berdasarkan gambar" dengan jumlah skor 40. Indikator ini mendapatkan nilai terendah karena anak masih ada beberapa anak yang belum bisa menyebutkan nama benda dan fungsinya berdasarkan gambar. Berdasarkan data di atas dapat diketahui terdapat peningkatan, pada saat pretest skor yang diperoleh secara keseluruhan sebesar 129 dengan rata-rata 43\% berada pada kriteria MB meningkat menjadi 216 dengan rata-rata $72 \%$ kriteria BSH. Jika dilihat dari perorangan terdapat anak dengan kategori BSH sebanyak 11 orang anak dengan persentasi 73,33\%. Anak pada kategori BSB sebanyak 4 orang anak dengan persentasi $\%$ 26,66\%. Kategori BB sebanyak 0 dengan persentasi $0 \%$. Anak pada kategori MB sebanyak 0 dengan persentase $0 \%$. Berarti perlekuan yang diberikan dalam penelitian ini sudah efektif untuk meningkatkan kesiapan membaca anak usia 3-4 tahun adapun, sebesar konstribusi perlakuan memang belum begitu besar dalam kategori sedang (51,16\%). Artinya media dadu putar untuk meningkatkan kesiapan membaca anak usia 3-4 tahun sebesar $(51,16 \%)$. Kriteria sedang ini dapat dipengaruhi karena media dadu putar yang digunakan oleh 15 orang anak secara bergantian. Kondisi ini menyebabkan kurang banyaknya kesempatan anak untuk memainkan media. Oleh karena itu, penggunaan satu media dadu putar masih kurang dengan jumlah anak 15 dan perlu penambahan dua media lagi sehingga satu media dapat digunakan oleh 6-7 orang anak. Dengan demikian kesempatan bermain anak akan lebih banyak sehingga tujuan penggunaan media dapat tercapai secara maksimal. Berarti ada faktor lain yang berkontribusi lebih besar sekitar 48,84\%. Terhadap peningkatan kesiapan membaca anak usia 3-4 tahun. Begitu juga penelitian Rita Kurnia (2017) dalam pembelajaran bahasa pada jenjang pendidikan taman kanak-kanak, guru harus kreatif untuk mengadakan atau membuat media pembelajaran yang diperlukan sesuai dengan tema dan sub tema yang akan diajarkan. (Kurnia, 2018) mengatakan pemanfaatan media, sumber belajar, dan alat permainan edukatif perlu dilakukan modifikasi media serta melalui cerita bergambar dapat meningkatkan konsep pengetahuan tentang lingkungan pada anak usia dini.

Pembelajaran bahasa pada jenjang pendidikan anak usia dini, guru harus kreatif untuk mengadakan atau membuat media pembelajaran yang diperlukan sesuai dengan tema dan subtema yang akan diajarkan. Dari hasil penelitian (Zubaida, 2016) yang dilakukan, terjadi peningkatan sebesar $51 \%$ dari siklus I ke siklus II. Dengan adanya peningkatan yang terjadi pada siklus II, ini menunjukkan bahwa anak sudah memiliki kesiapan unuk 
membaca. Hal ini dimaksudkan agar kemampuan membaca anak menjelang memasuki pendidikan formal (Sekolah Dasar) telah memiliki bekal yang cukup untuk mengikuti pembelajaran bahasa. Meskipun pembelajaran bahasa pada jenjang anak usia dini masih bersifat pra operasional, guru tetap wajib mempersiapkan anak didiknya secara baik agar pada saat anak tersebut akan memasuki pendidikan selanjutnya yang bersangkutan tidak menemui kendala yang berarti.

\section{KESIMPULAN DAN SARAN}

Berdasarkan hasil penelitian dan pembahasan, maka dapat ditarik kesimpulan sebagai berikut:

Sebagian besar kesiapan membaca pada anak usia 3-4 tahun sebelum diberikan perlakuan (treatment) media dadu putar di TK Tunas Cahaya Kurnia Riau berada pada kategori mulai berkembang (MB). Artinya anak mulai memperlihatkan keinginan untuk meminta dibacakan buku namun sebagian besar belum mampu pada indikator lain. (2) Sesudah diberikan perlakuan (treatment) media dadu putar untuk meningkatkan kesiapan membaca anak usia 3-4 tahun di TK Tunas Cahaya Kurnia Riau. Ternyata seluruh indikator yang diukur (posttest) berada pada kategori BSH dan BSB. Berarti ada perubahan kesiapan membaca anak usia 3-4 tahun dari sebelum dan sesudah perlakuan diberikan dalam penelitian. (3) Terdapat pengaruh yang signifikan penggunaan media dadu putar untuk meningkatkan kesiapan membaca anak usia 3-4 tahun di TK Tunas Cahaya
Kurnia Riau, sebelum dan sesudah perlakuan (treatment) dengan memberikan perlakuan berupa media dadu putar. Besar pengaruhnya yaitu $50,87 \%$ berdasarkan kriteria penilaian Gain Ternormalisasi berada pada kategori sedang.

\section{DAFTAR PUSTAKA}

Ahmad Susanto. (2011). Perkembangan anak usia dini. Jurnal Golden Age Hamzanwadi University.

Chairilsyah, D., \& Kurnia, R. (2018). Teacher Assessment to School Readiness on the 5-6 Year-Old Children in State Kindergarten in Pekanbaru (Motoric Physical, Social Emotional, Moral, Language, and Cognitive Aspect). JOURNAL OF EDUCATIONAL SCIENCES. https://doi.org/10.31258/jes.2.2.p.7 4-82

Fahim, M., \& Mustafa, S. J. (2001). Evidence for the presence of A1 adenosine receptors in the aorta of spontaneously hypertensive rats. British Journal of Pharmacology. https://doi.org/10.1038/sj.bjp.0704 433

King, A. W., \& With, K. A. (2002). Dispersal success on spatially structured landscapes: When do spatial pattern and dispersal behavior really matter? Ecological Modelling. https://doi.org/10.1016/S03043800(01)00400-8

Kurnia, R. (2012). Konsepsi Bermain dalam menumbuhkan Kreativitas 
Pada Anak Usia Dini. Educhild.

Kurnia, R. (2014). Pendidikan Gizi untuk Anak Usia Dini. Educhild: Jurnal Pendidikan Sosial Dan Budaya.

Kurnia, R. (2018). PENGEMBANGAN KEMAMPUAN MENULIS ANAK USIA DINI DENGAN TEMA ALAM SEMESTA. EDUCHILD.

Kurnia, R., \& Solfiah, Y. (2018). PENGARUH MEDIA PENSIL KARAKTER ANIMASI UPIN DAN IPIN TERHADAP KEMAMPUAN MENULIS ANAK. JPUD - Jurnal Pendidikan Usia Dini. https://doi.org/10.21009/jpud.122.1 5

Majzub, R., \& Kurnia, R. (2010). Reading readiness amongst preschool children in Pekanbaru Riau. Procedia - Social and Behavioral Sciences. https://doi.org/10.1016/j.sbspro.20 10.12.202

Novianti, R. (2015). Pengembangan permainan roda putar untuk meningkatkan kemampuan berhitung angka anak usia 5-6 tahun. Jurnal Educhild.

Pallant, J. (2013). A step-by-step guide to data analysis using SPSS version 15. In Open University Press, Maidenhead.

Roring, C. M. (2013). Contribution of race, primary language, family structure and pre-kindergarten attendance to the odds of being classified as having a specific learning disability by the third grade. In Dissertation Abstracts International Section A: Humanities and Social Sciences.

Ryoo, J. H., Molfese, V. J., Brown, E. T., Karp, K. S., Welch, G. W., \& Bovaird, J. A. (2015). Examining factor structures on the Test of
Early Mathematics Ability - 3: A longitudinal approach. Learning and Individual Differences. https://doi.org/10.1016/j.lindif.201 5.06 .003

Solfiah, Y., Risma, D., -, H., \& Kurnia, R. (2019). THE KNOWLEDGE OF EARLY CHILDHOOD EDUCATION TEACHERS ABOUT NATURAL DISASTER MANAGEMENT.

KINDERGARTEN: Journal of Islamic Early Childhood Education.

https://doi.org/10.24014/kjiece.v2i 2.8090

Wahyuni, S., \& Reswita. (2018). Lowincome Family Environment: Subjective Well-Being and Children Learning Motivation. IOP Conference Series: Earth and Environmental Science, 175, 012103.

https://doi.org/10.1088/17551315/175/1/012103

Wahyuni, S., \& Reswita, R. (2017). Hubungan Kematangan Emosional terhadap Kemampuan Bersosialisasi Mahasiswa PGPAUD FKIP UNILAK. Lectura: Jurnal Pendidikan. https://doi.org/10.31849/lectura.v8i 2.351

Zubaida. (2016). Implementasi Pendidikan Karakter Anak Usia Dini. Madaniyah. 